\title{
MITI drops headlights for gene sequencing
}

Tokyo. Japan's powerful Ministry of International Trade and Industry (MITI) has taken a further step into genome research by converting a former car headlamp-testing facility into a state-of-the-art centre for sequencing DNA.

At the end of last month, MITI officials and some of Japan's leading molecular biologists gathered to celebrate the completion of the new sequencing centre, which has been installed over the past two years on the fourth floor of the ministry's International Trade and Industry Inspection Institute in western Tokyo.

Until now, MITI's involvement in genome research has been limited, as the field has been considered the responsibility of other ministries and agencies. The Ministry of Education, Science and Culture (MESC) oversees university research in the area, and the Ministry of Health and Welfare (MHW) funds medical research and related areas. Similarly, the Ministry of Agriculture, Forestry and Fisheries has a rice genome project, and the Science and Technology Agency, along with the MESC and the MHW, funds part of the human genome project.

Anxious not to tread on others' toes,

\section{Russian aid agency defends its actions}

London. INTAS, the body set up by seventeen European states to channel funds to scientists working in Russia and other states of the former Soviet Union, has defended itself against charges of being excessively bureaucratic in the handling of grants.

The charges were made last month by the European Union's research commissioner, Edith Cresson, who said the European Commission was not prepared to provide increased funding to INTAS until it raised the effectiveness with which grants were managed (see Nature, 374, 203; 1995).

But in a statement issued in Brussels last week, INTAS says that, since it is handling public funds, it has had to ensure their "reliable and transparent management, distribution and transfer" in accordance with the legal frameworks of the newly independent states, its own member states, and the EU.

"The criticisms should be viewed in the context of these principles and the challenging, complex ever-changing environment of the NIS," the statement adds, claiming that "INTAS has succeeded in establishing adequate solutions to overcoming these obstacles," for example by negotiating favourable treatment for taxes and customs duties.

INTAS officials claim that 500 out of 1,000 multilateral research projects selected for support have received initial funding and are already operational. David Dickson
MITI's entry into genome research is under a facility entitled the Biotechnology Inspection Centre. The institute in which it is based used to be an important part of MITI's postwar drive to promote exports, but is undergoing a radical transformation as it seeks new tasks for its 460 technical staff.

Other floors at the institute will be devoted to inspection activities related to implementation of a new product liability law, and a law designed to prevent the proliferation of chemical weapons.

Work is already underway at the centre on sequencing the genome of Pyrococcus shinkai, a deep-sea bacterium collected from a volcanic vent in the Okinawa trough by Japan's deep-sea submersible Shinkai 6000 . It is hoped that heat-resistant proteins from

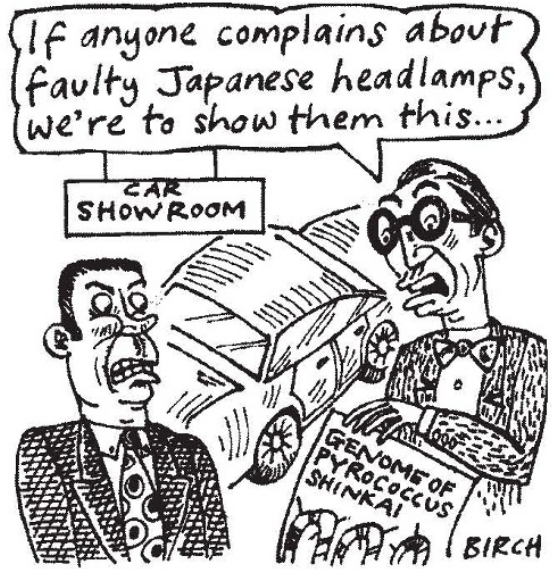

the bacterium can be isolated for possible use in the biotechnology industry.

With technical advice from Hiroaki Shizuya of the California Institute of Technology in the United States, 26 staff at the centre have already completed a physical map of the bacterium's genome. Michio Oishi, of Tokyo University's Institute of Molecular and Cellular Biosciences and one of the centre's advisers, says the researchers hope to have sequenced the whole genome

within about two years.

The genome is quite short - just under 2 megabases in length - and its relatively low guanine-cytosine content makes sequencing comparatively easy. Nevertheless, Oishi claims that it will be a remarkable achievement if the centre is able to complete the sequencing by 1997. An international project to sequence the 12.8 megabases of the yeast genome, for example, is not expected to be completed until around the same time, while another to sequence the 4.7 megabases of the Escherichia coli genome is making even slower progress (see Nature 368, 383; 1994)

But many observers remain concerned about whether the researchers at the sequencing facility, in spite of its ambitious goals, will be able to interpret and apply the data it is collecting. The staff are enthusiastic about their work, and have access to the latest sequencing equipment and computers. But they have no experience in genome research.

Furthermore, MITI itself has only limited expertise to draw on from its own research institutes, while Japan's traditional bureaucratic hurdles make it hard for the ministry to involve university researchers.

Such expertise is not totally absent. MITI can use its new National Institute of Bioscience and Human Technology in Tsukuba science city, and the ministry is also backing another DNA sequencing facility, the Kazusa DNA Research Institute, funded by the Chiba prefectural government (see Nature 372, 6; 1994). Scientists at both institutes will be able to help in the interpretation of data produced by the new sequencing centre in Tokyo.

But some leaders of Japan's genome research are even sceptical about Kazusa, dismissing it as merely a "local project". Given such comments, MITI seems likely to face an uphill battle in winning domestic recognition for its efforts in the field.

David Swinbanks

\section{Ecologist tipped for UK science post}

London. Robert May, Royal Society research professor of zoology at the University of Oxford, is being tipped as the most likely successor to Sir William Stewart as the next chief scientific adviser to the British government, and head of the Office of Science and Technology.

May, 59, holds a PhD in theoretical physics from the University of Sydney, Australia, and was professor of biology at Princeton University in New Jersey before taking up his current post in Oxford in 1988. Although he has had little direct involvement in British science policy, he is widely respected as both a researcher - for example for his work on population dynamics and the mathematics of ecosystems - and a research administrator.

No firm decision has been taken on the successor to Stewart, who took up his post in 1990 , and whose contract comes to an end in June. Other names that have been mentioned as possible candidates include Alan Rudge, a director of BT and chairman of the Engineering and Physical Science Research Council, David Wallace, vice-chancellor of Loughborough University, and John Arbuthnott, vice-chancellor of the University of Stirling. 